\title{
Leaching of heavy metals from cementitious composites made of new ternary cements
}

\author{
Justyna Kuterasińska-Warwas ${ }^{1, *}$, and Anna Król ${ }^{2}$ \\ ${ }^{1}$ Institute of Ceramics and Building Materials, Opole, Poland \\ ${ }^{2}$ Opole University of Technology, Opole, Poland
}

\begin{abstract}
The paper presents a comparison of research methods concerning the leaching of harmful substances (selected heavy metal cations ie. $\mathrm{Pb}, \mathrm{Cu}, \mathrm{Zn}$ and $\mathrm{Cr}$ ) and their degree of immobilization in cement matrices. The new types of ternary cements were used in the study, where a large proportion of cement clinker was replaced by other non-clinker components - industrial wastes, ie. siliceous fly ash from power industry and granulated blast furnace slag from the iron and steel industry. In studied cementitious binders also ground limestone was used, which is a widely available raw material. The aim of research is determining the suitability of new cements for neutralizing harmful substances in the obtained matrices. The application of two research methods in accordance with EN 12457-4 and NEN 7275 intends to reflection of changing environmental conditions whom composite materials may actually undergo during their exploitation or storing on landfills. The results show that cements with high addition of non-clinker components are suitable for stabilization of toxic substances and the obtained cement matrices retain a high degree of immobilization of heavy metals at the level of $99 \%$.
\end{abstract}

\section{Introduction}

The present trend in the use of alternative fuels and waste materials in cement and concrete production may increase the risk of contamination of final products (Fig.1 1) [1-4].

Such activities raise some doubts due to the impact of such materials on the environment. This risk particularly concerns the increased content of certain harmful substances, such as heavy metals, which, as a result of contact with the water, can leach into the surrounding environment [5].

Many environmental studies carried out on cementitious materials with wastes from other industries have shown that these materials have a high degree of immobilization of heavy metals [3, 6-15].

This is due to the properties of hardened cement matrix, which has been used for many years as an effective and safe material in the process of permanent solidification of hazardous waste $[10,12,16]$.

The immobilization properties of cement matrix (i.e. mortar and concrete) correspond to hydrated calcium silicates and in particular C-S-H phase (calcium silicate hydrate). Hydrated calcium silicates are the dominant constituent of hardened cement pastes and can stand for up to $70 \%$ of the volume.

The amount and morphology of the C-S-H phase depends on the selection of binder components [17]. Some authors believe [18, 19] that the major factors influencing the immobilization potential of hydrated calcium silicates are the ability to incorporate foreign elements into the structure, the effect of hydrated calcium silicates as ion exchangers, low permeability of the CSH phase, acting as a barrier to particles migration and its large specific surface area (which gives the socalled sorption potential).

In addition, the $\mathrm{C}-\mathrm{S}-\mathrm{H}$ phase remains in the state of equilibrium with the liquid phase present in the pores and, depending on the concentration of calcium hydroxide at this stage, emits or takes up $\mathrm{Ca}^{2+}$ ions from the one.

The high $(>12.4) \mathrm{pH}$ of the liquid present in the pores favours the precipitation of hydroxides and other insoluble heavy metal compounds [3,18,20-21].

The evaluation of hereby paper assessed the immobilization properties of mineral matrices, made of selected types of composite cements of non-standard composition. Applied cements are the object of standardization work on the revision of the current cement standard (EN 197-1) [22-23]. These matrices solidified heavy metals $(\mathrm{Cu}, \mathrm{Cr}, \mathrm{Pb}$ and $\mathrm{Zn}$ ) previously introduced into them as soluble salts.

The research is to show that matrices made of new types of composite cements will be capable of immobilizing contained heavy metals and what will be the amount of metals leaching out, depending on the application of a different leaching scenario, i.e. the test method used.

The effect of addition of heavy metals on the strength of cement mortars (after 7, 28 and 90 days of hardening) was also determined.

\footnotetext{
* Corresponding author: j.kuterasinska@icimb.pl
} 


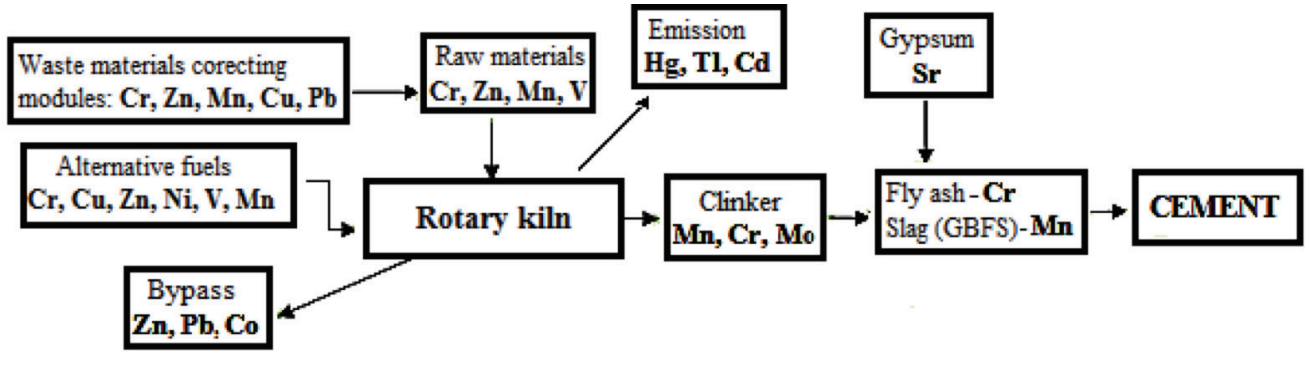

Fig. 1. Sources of heavy metals in cement production $[4,12]$.

\section{Selection oftest methods - reflecting the two leaching scenarios}

There could be several scenarios according to which the material can be leached. The impact on the amount of leachates is primarily affected by the environmental conditions where the material is exposed (temperature variables, leaching liquid and its $\mathrm{pH}$, time and type of exposure, mechanical influences i.e. erosion, frost). Especially important is the $\mathrm{pH}$ of the leaching medium, which the lower, the more aggressively affects the exposed cement matrices, accelerating their dissolution and release of toxic elements [3,8, 24-27]. Moreover, the expression of the material content (particulate or monolithic) and its parameters such as porosity, expansion area or reactivity are critical [25-27]. The necessity to assess the release level of harmful substances from construction products is required by the Construction Products Directive [12, 28]. Particularly, when building materials become matrices solidifying waste from other industries, they should be subjected to appropriate environmental tests. Composites that solidify hazardous waste often end up in nature through practical use, such as civil engineering and communication works, but may also be deposited in landfills [12]. Since they are thus exposed to external factors, they may be subject to damage and loss of utility. Consequently, they should have good physical-mechanical properties that will ensure longevity in the long run. Durability is essential due to the fact of heavy metals being leached into the aquatic or soil environment which the matrices are in contact with. In the study the leaching teste were performed using 2 test methods. The first one is a dynamic one, batch-based test (according to EN 12457: 2006) and is used to characterize waste destined for landfill of a given type (I scenario - fragmented material) [29-30]. The second one is a method performed according to the Dutch standard NEN 7375: 2004 [31] and is considered as a static one. This method allows to reflect the environmental conditions in which the material is constantly immersed in the leaching liquid in monolithic form (II scenario).

\section{Materials and test methods}

\subsection{Materials used for testing}

Four types of mortars made of new types of composite cements were subjected to leaching tests. The increased content of a mixture of two non-clinker main components in their composition is a key feature of these cements. These binders are present in the threecomponent combinations: K-S-L/LL, K-S-V and K-VL/LL (K-clinker, S-granulated blast furnace slag, Vsiliceous fly ash, L/LL - limestone). Cements were obtained by mixing finely ground non-clinker components with a semi-finished product acting as clinker carrier. The semi-finished product (C) used was characterized by an increased content of $\mathrm{SO}_{3}(5.1 \%)$ and a high specific surface $\left(6200 \mathrm{~cm}^{2} / \mathrm{g}\right)$. Binders were mixed in a laboratory homogenizer in appropriate proportions - each mixture was homogenized for $30 \mathrm{~min}$ (Table 1).

Table 1. The composition of tested cements

\begin{tabular}{|c|l|c|c|c|c|}
\hline \multirow{2}{*}{ No. } & \multirow{2}{*}{ Cement type } & \multicolumn{4}{|c|}{$\begin{array}{c}\text { Percentage content of } \\
\text { component, [\%] }\end{array}$} \\
\cline { 3 - 7 } & & $\mathrm{C}$ & $\mathrm{S}$ & $\mathrm{LL}$ & $\mathrm{V}$ \\
\hline \hline 1. & CEM II/ C $(30 \% \mathrm{~S}+10 \% \mathrm{LL})$ & 60 & 30 & 10 & - \\
\hline 2. & CEM II/ C $(30 \% \mathrm{~V}+10 \% \mathrm{LL})$ & 60 & - & 10 & 30 \\
\hline 3. & CEM VI $(45 \% \mathrm{~S}+10 \% \mathrm{LL})$ & 45 & 45 & 10 & - \\
\hline 4. & CEM VI $(45 \% \mathrm{~S}+10 \% \mathrm{~V})$ & 45 & 45 & - & 10 \\
\hline
\end{tabular}

The mortars were prepared according to the formula given in PN-EN 196-1 [32] by mixing $450 \mathrm{~g}$ of selected composite cement, $1350 \mathrm{~g}$ of standard sand (maximal grain size $\mathrm{d} \leq 2 \mathrm{~mm}$ ) and $225 \mathrm{ml}$ of water.

Prepared mortars were characterized by a water/cement ratio $\mathrm{w} / \mathrm{c}=0.5$. Samples in the shape of rectangular

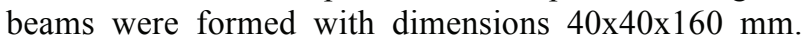
Samples were stored under conditions specified in PNEN 197-1 [22], i.e. at $\mathrm{t}=20 \pm 1^{\circ} \mathrm{C}$, and humidity RH> $90 \%$.

Heavy metal ions $\mathrm{Cr}^{6+}, \mathrm{Cu}^{2+}, \mathrm{Zn}^{2+}$ and $\mathrm{Pb}^{2+}$ ) were introduced into the prepared mortars as their soluble salts: $\mathrm{Na}_{2} \mathbf{C r}_{2} \mathrm{O}_{7} \cdot 2 \mathrm{H}_{2} \mathrm{O}, \quad \mathbf{C u}\left(\mathrm{NO}_{3}\right)_{2} \cdot 3 \mathrm{H}_{2} \mathrm{O}, \quad \mathbf{P b}\left(\mathrm{NO}_{3}\right)_{2}$, $\mathbf{Z n}\left(\mathrm{NO}_{3}\right)_{2} \cdot 6 \mathrm{H}_{2} \mathrm{O}$. Heavy metals were added to mortars in the amount of $0.2 \%$ calculated on the metal cation with respect to the binder mass (heavy metal salts dissolved in mixing water). 


\subsection{Research methodology}

Scope of the study consisted of the compressive strength of mortars after 7, 28 and 90 days of hardening (with and without heavy metals addition), additionally, water extracts from their debris were made (I leaching scenario). In parallel, identically prepared mortars, freshly formed after being demoulded, were placed in containers and poured with deionized water in a ratio of water to a sample volume of 5: 1 (II scenario). Eluates were collected after the specified time intervals, i.e. 0.25 , $1,2.25,4,9,16,36$ and 64 days. The mortars were made and tested according to the procedure stated in the standard for cement testing PN-EN 196-1: 2006 [32]. The water extracts for the I leaching scenario were constructed according to the methodology described in the standard PN-EN 12457-4: 2006 (maximal particle size diameter $\mathrm{d} \leq 10 \mathrm{~mm}$, water extract made at a liquid to solid ratio of $1 / 10$, shaking time $24 \mathrm{~h}$ ) [30] Water extracts for the monolithic sample, according to the second leaching scenario, were made in compliance with the proceedings of the Dutch standard NEN 7375: 2004 [31]. An Inductively Coupled Plasma Mass Spectrometer (ICP MS) was used to read the concentrations of heavy metals in the water extracts. The microstructure of pastes with the addition of selected heavy metals was also investigated using the scanning electron microscope (SEM) in combination with the X-ray diffraction microscope (EDS).

\section{Test results}

The compressive strength of mortars made of new types of composite cements with previously introduced soluble heavy metal salts was studied. The results were referred to comparative mortars (without added metal). In order to determine the effect of the composition of individual cements on the degree of immobilization of heavy metals in formed matrices, leaching of heavy metal was investigated using the two test methods.

\subsection{The effect of heavy metal addition on the strength of mortars}

Fig. 2 shows the results of the compressive strengths after 7, 28 and 90 days of hardening of mortars prepared from the analyzed cements. The results of mortars with heavy metals addition were compared with mortars without the additives.

On the basis of mortar strength results obtained after the analyzed periods, it can be seen that $0.2 \%$ addition of heavy metal salts slightly decreases the strength level. For mortars that had reached the age of 90 days, the addition of copper in two cases (CEM II/C (30\% S + $10 \%$ LL) and CEM VI $(45 \% \mathrm{~S}+10 \% \mathrm{~V}))$ marginally increased strength ( $1 \%$ and $4 \%$ accordingly). The addition of zinc and lead usually resulted in a mild decrease in strength over all periods (from about $1 \%$ to $12 \%)$. The lowest decrease in strength was observed for CEM VI cement $(45 \% \mathrm{~S}+10 \% \mathrm{~V})$, and even an increase of $1.6 \%$ for chromium and $3.2 \%$ for lead addition was
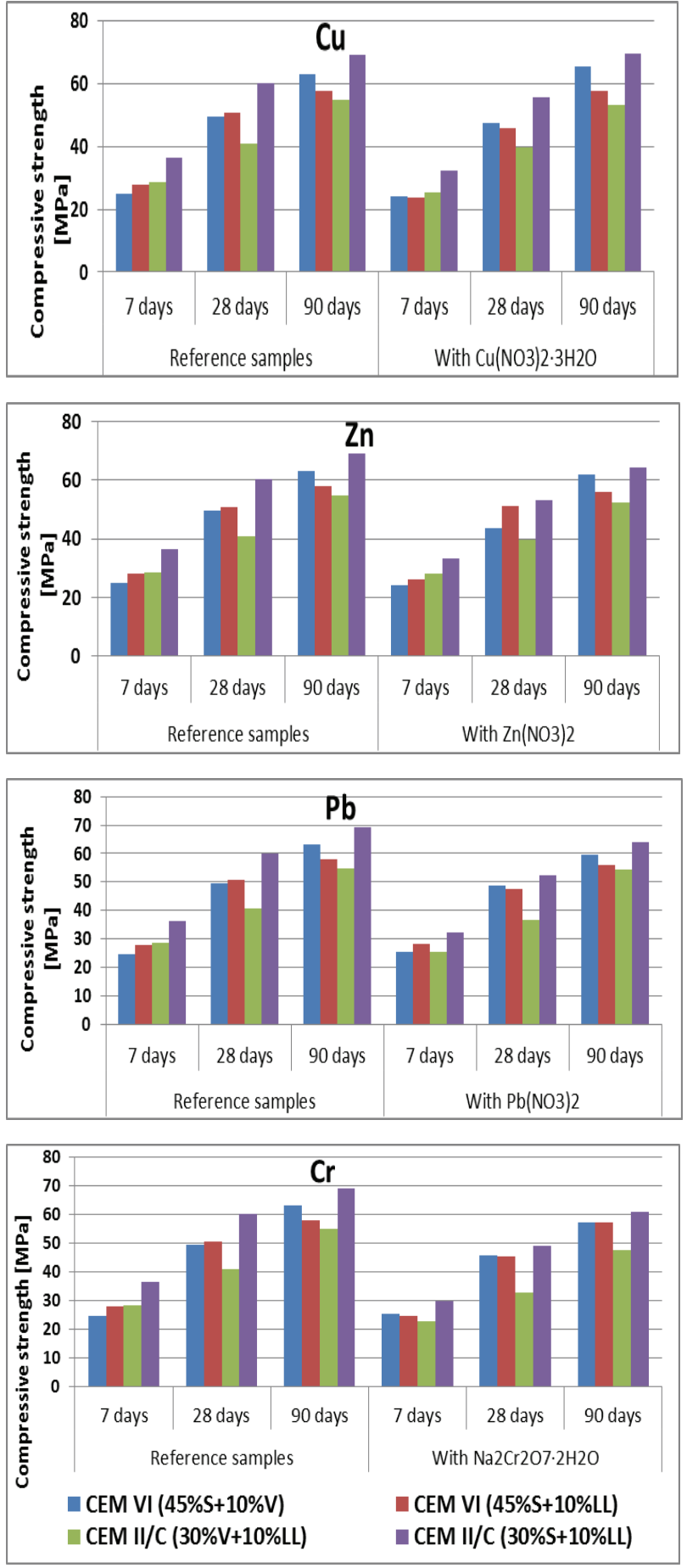

Fig. 2. Comparison of the strengths of 7, 28 and 90-day mortars made of composite cements without and with the addition of heavy metal $(\mathrm{Cr}, \mathrm{Cu}, \mathrm{Zn}, \mathrm{Pb}$ salts).

observed in strength after 7 days of hardening. Nevertheless, for the remaining samples of composite cements, the addition of chromium salts had the most impact on the strength reduction (for 7 and 28-day mortars CEM II/C $(30 \% \mathrm{~S}+10 \% \mathrm{LL})$ the drop exceeded $20 \%$. Such a slight impact of $0.2 \%$ of heavy metal addition on the mechanical properties of the mortars indicates the good quality of tested matrices, which will certainly be beneficial for the degree of immobilization of heavy metals in their structure. 


\subsection{Leaching of heavy metals from crushed mortars (I leaching scenario)}

Concentrations of individual heavy metal ions in the eluates obtained from crushed cement mortars after 7, 28 and 90 days of hardening are shown in Table 2. It has been found that leaching of metals for mortar at early stages ( 7 days) is significantly higher than mortars after 90 days. This is particularly evident on the example of chromium and lead. This is due to the lesser degree of cement matrix hydration over a shorter period of time, the consequence of which is relatively less compact microstructure of the paste. This has a positive influence on the leaching of heavy metals, which should in principle be adsorbed by the $\mathrm{C}-\mathrm{S}-\mathrm{H}$ phase. This phase, at early hardening period already occupies a substantial part of it, however, its amount increases with time, which is due to the continuous hydration of active phases of cement binder. After 28 days of mortar sample curing process, a significant decrease in leaching of analyzed heavy metals can be observed, which is undoubtedly due to the greater part of C-S-H phase.

Table 2. Concentration of heavy metals in eluates in 7,28 and 90-day mortars dosed with their salts.

\begin{tabular}{|c|c|c|c|c|c|}
\hline \multirow{2}{*}{$\begin{array}{l}\text { Sample } \\
\text { age }\end{array}$} & \multirow{2}{*}{$\begin{array}{c}\text { Cement } \\
\text { type }\end{array}$} & \multicolumn{4}{|c|}{$\begin{array}{l}\text { Concentration of heavy metal ions } \\
\text { in eluat }\left[\mu \mathrm{g} / \mathrm{dm}^{3}\right]\end{array}$} \\
\hline & & $\mathrm{Cu}^{2+}$ & $\mathbf{Z n}^{2+}$ & $\mathbf{P b}^{2+}$ & $\mathrm{Cr}^{6+}$ \\
\hline 7 days & \multirow{3}{*}{$\begin{array}{l}\text { CEM II/C } \\
(30 \% \text { S } \\
10 \% \text { LL) }\end{array}$} & 5.40 & 13.40 & 18.75 & 2151.5 \\
\hline 28 days & & 0.18 & 2.78 & 2.84 & 1166.1 \\
\hline 90 days & & 0.38 & 0.01 & 0.21 & 726.7 \\
\hline 77 days & \multirow{3}{*}{$\begin{array}{l}\text { CEM II/ } \\
\text { C } \\
(30 \% \text { V+ } \\
10 \% L L)\end{array}$} & 1.27 & 13.60 & 309.75 & 2951.0 \\
\hline 28 days & & 1.29 & 0.05 & 3.44 & 2333.4 \\
\hline 90 days & & 1.22 & 0.02 & 0.22 & 2312.7 \\
\hline 7 days & \multirow{3}{*}{$\begin{array}{l}\text { CEM VI } \\
(45 \% \text { S+ } \\
10 \% \text { LL })\end{array}$} & 2.90 & 14.00 & 109.54 & 2112.5 \\
\hline 28 days & & $<0.05$ & $<0.05$ & 1.60 & 1126.8 \\
\hline 90 days & & $<0.05$ & 0.01 & 0.17 & 561.6 \\
\hline 7 days & \multirow{3}{*}{$\begin{array}{l}\text { CEM VI } \\
(45 \% \mathrm{~S}+ \\
10 \% \mathrm{~V})\end{array}$} & 1.96 & 14.60 & 252.43 & 2275.0 \\
\hline 28 days & & $<0.05$ & $<0.05$ & 1.60 & 650.4 \\
\hline 90 days & & 1.26 & 0.01 & 0.17 & 371.8 \\
\hline
\end{tabular}

Considering the dependence of heavy metals on the composition of tested cements, it can be seen that most metals are leached out of the matrix on fly ash-lime cement (CEM II/C $(30 \% \mathrm{~V}+10 \% \mathrm{LL})$. Thus, it may indicate that the fly ash-lime cement matrix has the least compact microstructure.

The compressive strength results, which are the lowest for this type of cement described in hereby study may reflect the situation (Fig 2).

Since a specific amount of individual heavy metal cations was added to the mortar, their total content in the mortar was known. Hence, their level of immobilization in the matrices examined was calculated (Table 3).

The results show that analyzed heavy metals are effectively retained inside mortars on new types of composite cements. Such matrices are characterized by a high level of heavy metal immobilization, mainly of
Table 3. Immobilization level of heavy metals in cement pastes.

\begin{tabular}{|c|c|c|c|c|c|}
\hline \multirow{2}{*}{$\begin{array}{l}\text { Sample } \\
\text { age }\end{array}$} & \multirow{2}{*}{ Cement type } & \multicolumn{4}{|c|}{$\begin{array}{c}\text { Heavy metals immobilization } \\
\text { level [\%] }\end{array}$} \\
\hline & & $\mathrm{Cu}^{2+}$ & $\mathrm{Zn}^{2+}$ & $\mathbf{P b}^{2+}$ & $\mathrm{Cr}^{6+}$ \\
\hline 7 days & \multirow{3}{*}{$\begin{array}{l}\text { CEM II/ C } \\
(30 \% \mathrm{~S}+10 \% L L)\end{array}$} & 99.99 & 99.99 & 99.99 & 98.34 \\
\hline 28 days & & 100.00 & 99.99 & 99.99 & 99.10 \\
\hline 90 days & & 100.00 & 100.00 & 100.00 & 99.44 \\
\hline $7 \mathrm{da}$ & \multirow{3}{*}{$\begin{array}{l}\text { CEM II/ C } \\
(30 \% \mathrm{~V}+10 \% \mathrm{LL})\end{array}$} & 99.99 & 99.99 & 99.84 & 97.73 \\
\hline 28 days & & 99.99 & 100.00 & 99.99 & 98.20 \\
\hline 90 days & & 99.99 & 100.00 & 100.00 & 98.22 \\
\hline 7 days & \multirow{3}{*}{$\begin{array}{l}\text { CEM VI } \\
(45 \% \mathrm{~S}+10 \% \mathrm{LL})\end{array}$} & 99. & 99.99 & 99.94 & 98.38 \\
\hline 28 days & & 100.00 & 100.00 & 99.99 & 99.13 \\
\hline 90 days & & 100.00 & 100.00 & 100.00 & 99.56 \\
\hline 7 days & \multirow{3}{*}{$\begin{array}{l}\text { CEM VI } \\
(45 \% \mathrm{~S}+10 \% \mathrm{~V})\end{array}$} & 99.99 & 99.99 & 99.87 & 98.25 \\
\hline 28 days & & 100.00 & 100.00 & 99.99 & 99.50 \\
\hline 90 days & & 99.99 & 100.00 & 100.00 & 99.71 \\
\hline
\end{tabular}

$99.8 \%-100 \%$ for $\mathrm{Cu}, \mathrm{Zn}$ and $\mathrm{Pb}$ - depending on the age of the sample. The least effective cement composition for immobilization of heavy metals has been performed by the combination of siliceous fly ash and limestone in CEM II/C cement $(30 \% \mathrm{~V}+10 \% \mathrm{LL})$, which clearly shows the chromium immobilization ratio of approximately $97.73 \%$ for mortars after 7 days of hardening and $98.22 \%$ for mortars after 90 days.

Despite the fact that tested samples were crushed and subjected to dynamic testing, the level of immobilization of selected heavy metals in the analyzed cement matrices turned out to be high. The results obtained therefore prove, that there are the possibilities to apply these cement types in the stabilization of industrial waste containing high concentrations of heavy metals.

\subsection{Immobilization of heavy metals from monolith (II leaching scenario)}

In order to reflect the environmental conditions in which fresh cement composites are subjected to constant water stress (e.g. concrete retention tanks, drainage wells and drainage water receivers), monolithic samples were tested. The amount of leachates was observed at fixed intervals, i.e. after $0.25,1,2.25,4,9,16,36$ and 64 days [31].

Table 4 gives the concentrations of heavy metals in the eluates for the various test periods.

The leachability test carried out on monolithic samples showed an identical trend in the leaching of individual metals from the test matrices.

Chromium from the matrix on fly ash - lime cement CEM II/C (30\% V + 10\% LL) was leached in the largest amount, the least was copper. 
Table 4 Aggregated concentration of heavy metals in water extracts made from mortars dispensed with their salts after a specified period of time.

\begin{tabular}{|c|c|c|c|c|c|c|c|c|}
\hline \multirow{3}{*}{ Cement types } & \multicolumn{8}{|c|}{$\begin{array}{l}\text { Concentration of heavy metal ions in eluates }\left[\mu \mathrm{g} / \mathrm{dm}^{3}\right] \text { after specified } \\
\text { time [days] }\end{array}$} \\
\hline & 0.25 & 1 & 2.25 & 4 & 9 & 16 & 36 & 64 \\
\hline & \multicolumn{8}{|c|}{$\mathrm{Cu}^{2+}$} \\
\hline \begin{tabular}{l|l} 
CEM II/ \\
C(30\%S+10\%LL $)$ \\
\end{tabular} & 2.35 & 2.54 & 3.1 & 5.56 & 6.09 & 6.28 & 6.33 & 9.14 \\
\hline $\begin{array}{l}\text { CEM II/ } \\
\text { C(30\% }+10 \% L L)\end{array}$ & 1.51 & 2.2 & 3.16 & 3.71 & 4.24 & 5.0 & 7.66 & 10.37 \\
\hline $\begin{array}{l}\text { CEM VI } \\
(45 \% \mathrm{~S}+10 \% \mathrm{LL})\end{array}$ & 2.43 & 2.59 & 3.13 & 5.64 & 6.09 & 6.38 & 6.67 & 8.85 \\
\hline \multirow[t]{2}{*}{$\begin{array}{l}\text { CEM VI } \\
(45 \% \mathrm{~S}+10 \% \mathrm{~V}) \\
\end{array}$} & 2.06 & 2.13 & 2.63 & 2.94 & 3.59 & 4.03 & 4.96 & 10.11 \\
\hline & \multicolumn{8}{|c|}{$\mathrm{Zn}^{2+}$} \\
\hline $\begin{array}{l}\text { CEM II/ } \\
\text { C(30\%S+10\%LL) }\end{array}$ & 6.71 & 22.25 & 22.3 & 23.51 & 23.56 & 23.61 & 23.66 & 36.83 \\
\hline $\begin{array}{l}\text { CEM II/ } \\
\text { C(30\% }+10 \% L L) \\
\end{array}$ & 264.79 & 305.55 & 305.6 & 324.18 & 324.23 & 324.28 & 324.33 & 337.34 \\
\hline $\begin{array}{l}\text { CEM VI } \\
(45 \% S+10 \% L L)\end{array}$ & 32.51 & 65.46 & 65.51 & 244.32 & 244.37 & 244.42 & 245.31 & 277.19 \\
\hline \multirow[t]{2}{*}{$\begin{array}{l}\text { CEM VI } \\
(45 \% \mathrm{~S}+10 \% \mathrm{~V}) \\
\end{array}$} & 130.51 & 211.74 & 211.79 & 211.84 & 211.89 & 212.16 & 215.29 & 237.55 \\
\hline & \multicolumn{8}{|c|}{$\mathbf{P b}^{2+}$} \\
\hline $\begin{array}{l}\text { CEM II/ } \\
\text { C(30\%S+10\%LL })\end{array}$ & 27.01 & 44.32 & 44.55 & 44.61 & 45.07 & 46.17 & 46.39 & 50.84 \\
\hline $\begin{array}{l}\text { CEM II/ } \\
\text { C(30\% }+10 \% L L) \\
\end{array}$ & 35.54 & 68.17 & 68.48 & 68.54 & 68.82 & 68.87 & 69.03 & 75.6 \\
\hline $\begin{array}{l}\text { CEM VI } \\
(45 \% S+10 \% L L) \\
\end{array}$ & 41.21 & 63.89 & 64.08 & 64.58 & 64.61 & 64.66 & 65.03 & 74.52 \\
\hline \multirow[t]{2}{*}{$\begin{array}{l}\text { CEM VI } \\
(45 \% \mathrm{~S}+10 \% \mathrm{~V}) \\
\end{array}$} & 35.61 & 62.43 & 62.67 & 62.79 & 62.81 & 62.94 & 63.05 & 69.1 \\
\hline & \multicolumn{8}{|c|}{$\mathrm{Cr}^{6+}$} \\
\hline $\begin{array}{l}\text { CEM II/ } \\
\text { C(30\%S+10\%LL) }\end{array}$ & 4569.5 & 6357.0 & 6713.2 & 6813.3 & 6886.75 & 6979.05 & 7148.05 & 7393.75 \\
\hline $\begin{array}{l}\text { CEM II/ } \\
\text { C(30\% }+10 \% L L) \\
\end{array}$ & 4602.0 & 7267.0 & 8391.5 & 8695.05 & 8808.15 & 8877.7 & 9083.75 & 9319.05 \\
\hline $\begin{array}{l}\text { CEM VI } \\
(45 \% S+10 \% L L) \\
\end{array}$ & 4114.5 & 5603.0 & 7663.5 & 7716.8 & 7803.25 & 7898.8 & 8045.7 & 8290.1 \\
\hline $\begin{array}{l}\text { CEM VI } \\
(45 \% \mathrm{~S}+10 \% \mathrm{~V})\end{array}$ & 741.0 & 3549.0 & 8365.5 & 8465.6 & 8572.85 & 8702.85 & 8909.55 & 9103.25 \\
\hline
\end{tabular}

As the mortar was used right after the demoulding process, the level of metals leached was significantly different compared to the results of the dynamic test [30]. In general, this level is considerably higher. The only exception is the amount of lead that leached from about 51 to $75 \mu \mathrm{g} / \mathrm{dm}^{3}$ until the last day of the test, and in the dynamic method for 7-day samples, its concentration was 109.54 to $309.8 \mu \mathrm{g} / \mathrm{dm}^{3}$ (except for the matrix on cement CEM II/C (30\% S + 10\% LL)). Looking at individual cement matrices, it can be stated, that matrix on CEM II/C $(30 \% \mathrm{~S}+10 \% \mathrm{LL})$ cement is the best retainer for zinc and lead, yet from the very beginning of the test. However, the greater Portland clinker content plays a significant role here - favors a greater intensity of hydration reaction and the formation of more C-S-H phase, a key factor in the heavy metals binding process. The highest amount of heavy metals leached within 6 to 24 hours (0.25-1 day) of the test.

\subsection{The influence of new cement type compositions on the immobilization of heavy metals.}

Referring to the composition of individual cements, it can be seen that the higher content of mineral additives (in favor of the decreasing amount of Portland clinker), especially blast furnace slag, results in reduced leaching of chromium the first day of stationary test [31]. This is particularly evident on the example of CEM VI cement $(45 \% \mathrm{~S}-10 \% \mathrm{~V})$. However, upon completion of the study, the total amount of washed chromium in this cement is higher when compared to CEM VI slag-lime cement (45\% S-10\% LL) containing the same proportion of mineral additives (55\%).

The observation shows that the addition of fly ash to cement with respect to limestone deteriorates the immobilization properties of the cement matrices in 
relation to all heavy metals analyzed. This is clearly indicated by the concentration of these elements in cement eluates with $30 \%$ of fly ash addition CEM II/C $(30 \% \mathrm{~V}+10 \% \mathrm{LL})$ (despite the higher content of clinker).

The pozzolanic reaction of fly ash in the cement system proceeds slowly, hence, such high content of fly ash in cement effectively slows down the formation of C-S-H phase, so crucial for binding of heavy metals. The addition of blast furnace slag affects the sealing of the cement matrix due to the reaction of portlandite $\left(\mathrm{Ca}(\mathrm{OH})_{2}\right)$ formed from the hydrolysis of clinker calcium silicates of with silica anions from the slag hydration process.

Aforementioned reaction results in an increased number of C-S-H phases in paste and a decrease in the capillary porosity of the hardened mixture, which hinders the diffusion of various substances [12].

Observing the increased leaching of chrome against other heavy metals, it should also be noted that chrome has a higher affinity for ettringite and calcium monosulphates than to the $\mathrm{C}-\mathrm{S}-\mathrm{H}$ phase alone.

The chemical structure of calcium sulfate enables the attachment of mono- or divalent ions (both anions and cations). Sulphoalumiantes enable chromium to be incorporated into their structure by replacing the sulphate group [1, 12, 19].

The worst immobilization properties for both test methods are performed by the composition of fly ashlime cement (CEM II/C $30 \% \mathrm{~V}+10 \% \mathrm{LL})$. Limestone in the cement composition acts as a microfiller, which in consequence increases the tightness of the cement matrix. Unfortunately, it is a raw material, considered as chemically inert in the cement system, which reduces the immobilization potential in relation to heavy metals. Furthermore, the correlation of limestone with siliceous fly ash (due to its high fineness, fly ash also acts as a micro aggregate), which as a pozzolanic additive, reacts slowly (depends on the amount of portlantide of the clinker phase reaction), will result in slower synthesis of the C-S-H phase, which, judging by the results, negatively affects immobilization and strength properties of the fly ash-limestone matrix (Table 3 and Fig. 2). Other slag-lime cements, containing more Portland clinker in their composition, perform better immobilization properties of heavy metals.

\subsection{Microstructure - SEM image}

Figs. 3-6 show the microstructure of selected cement pastes with heavy metals addition.

Microstructural observations were made after 90 days of hydration (until the tests were implemented they had been stored in the air conditioning cabinet at $20 \pm 2^{\circ} \mathrm{C}$ and relative humidity $>95 \%$ according to [32]).

Hydrating cement pastes without the addition of heavy metals show mainly the presence of the gel, compact
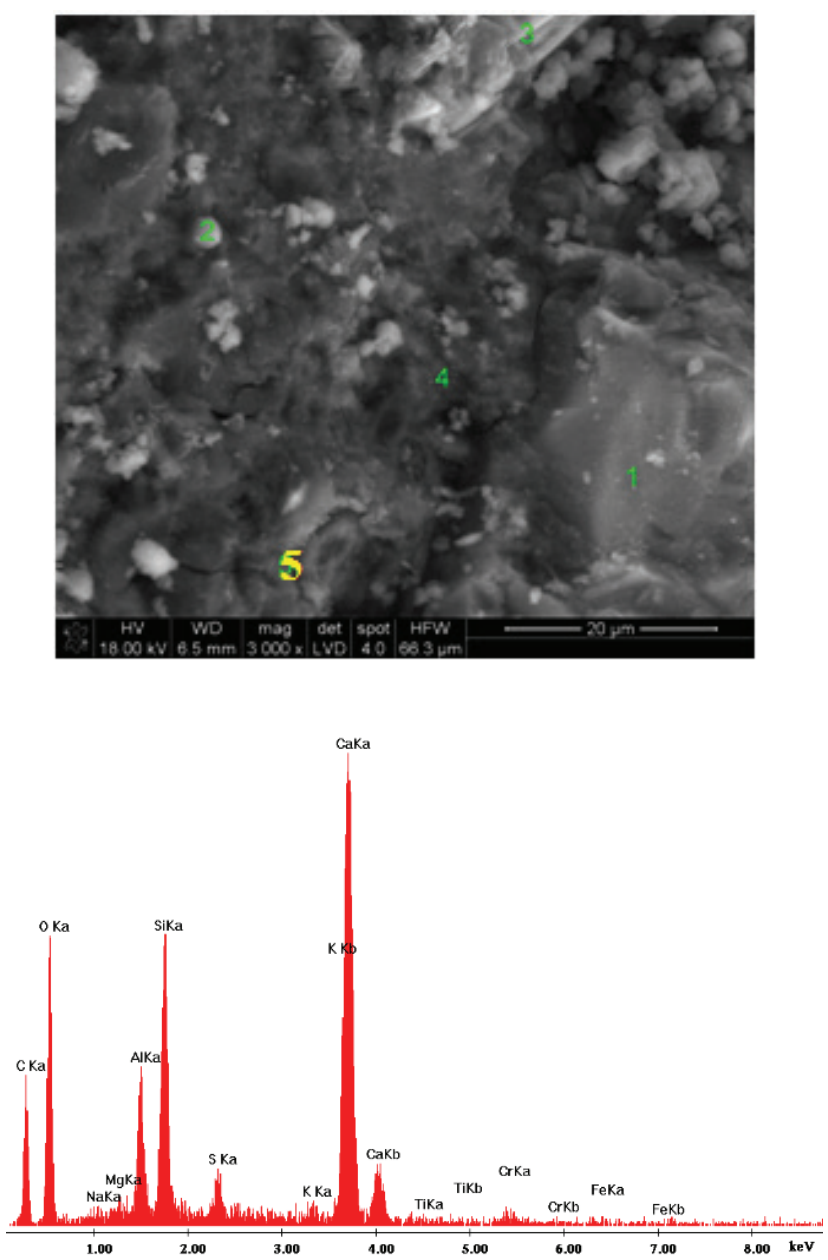

Fig. 3. Microstructure of paste on CEM VI $(45 \% \mathrm{~S}+10 \% \mathrm{~V})$ binder with the addition of chromium salt. Visible areas filled with C-S-H phase on slag particles and ash particle. The EDS analysis at point 5 indicates the presence of chromium ions embedded in the C-S-H phase.

C-S-H phase, but small areas of its fibrous, variant could also be observed.

In case of the addition of zinc, copper and lead salts, no significant differences were observed in pastes microstructure.

Only in the case of the addition of chromium ions to the slag cement paste (CEM VI $(45 \% \mathrm{~S}+10 \% \mathrm{LL}))$, a greater amount of fibrous C-S-H was found.

Chromium was also the only metal possible to identify by X-ray microanalysis. Probably the amount of metals introduced was too small to prove their presence by chemical spot analysis (EDS).

All the pastes showed also not fully reacted particles of individual components (fly ash, slag or limestone particles covered with small amounts of C-S-H phase (Figs. 3, 5 and 6).

Small amounts of ettringite and monosulfate also proved their presence. 

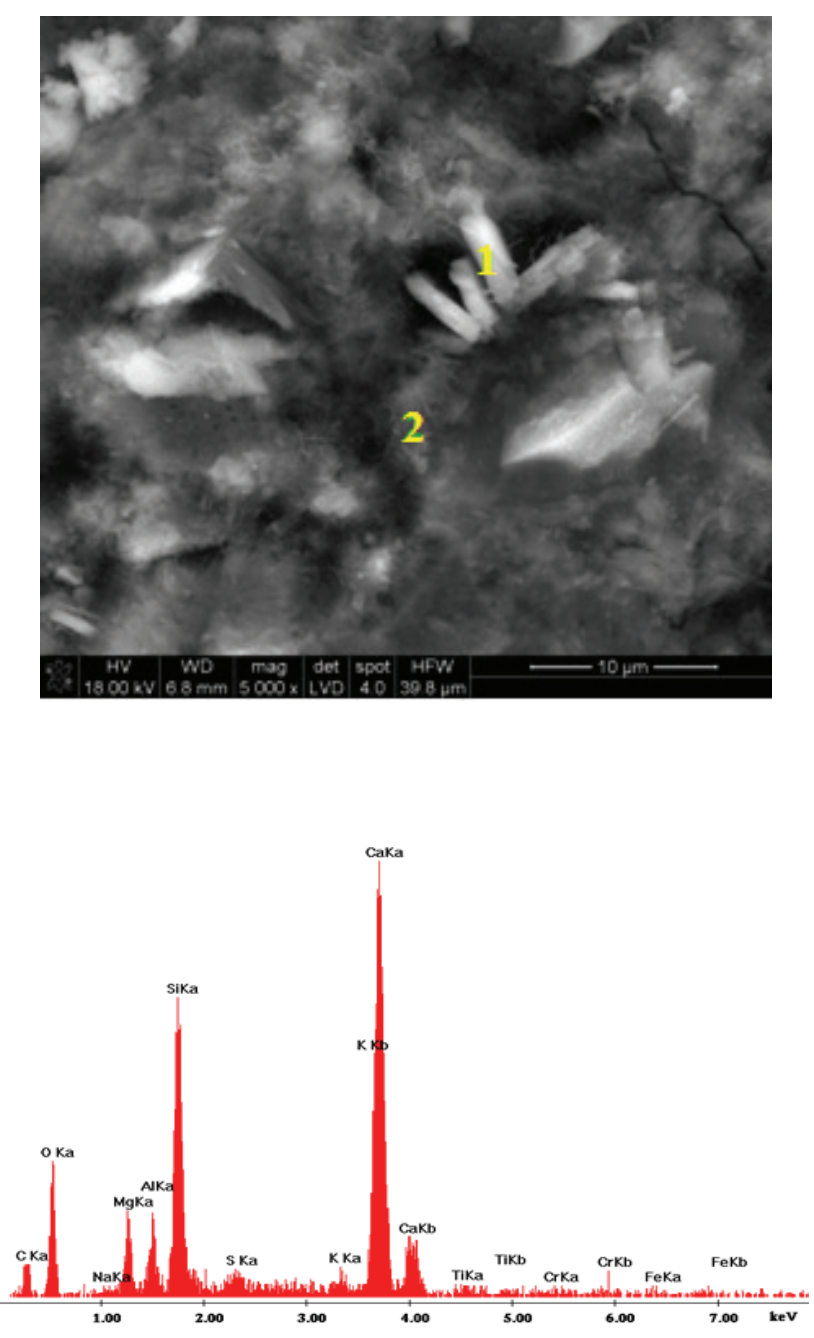

Fig. 4. Microstructure of paste on CEM VI (45\%S+10\%LL) binder with the addition of chromium salt. Gel phase C-S-H and calcium aluminate (point 1). The EDS analysis at point 2 indicates the presence of chromium ions embedded in the ettringite phase.

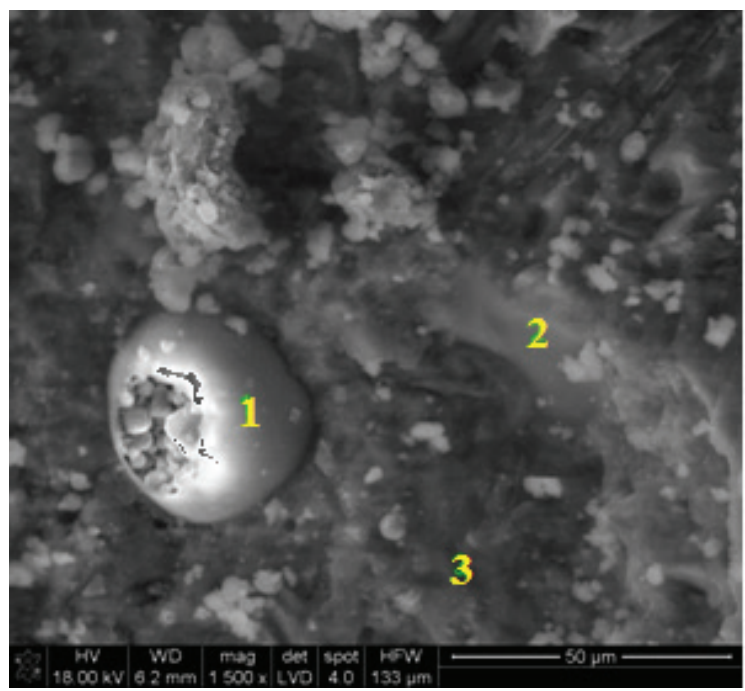

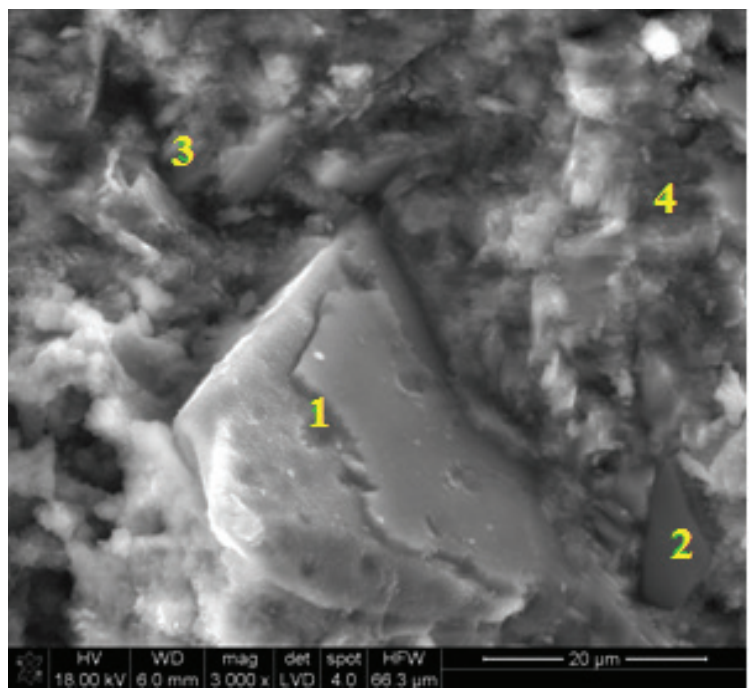

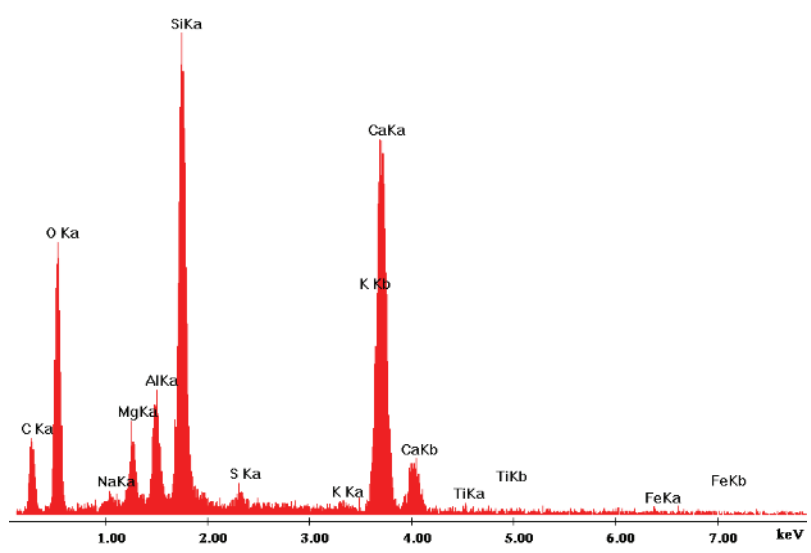

Fig. 5. Microstructure of paste on CEM VI $(45 \% \mathrm{~S}+10 \% \mathrm{LL})$ binder with the addition of zinc salt. Visible unreacted slag particle (EDS- point 1,point 2), compact C-S-H phase (point 4) and portlandite (point 3 ).

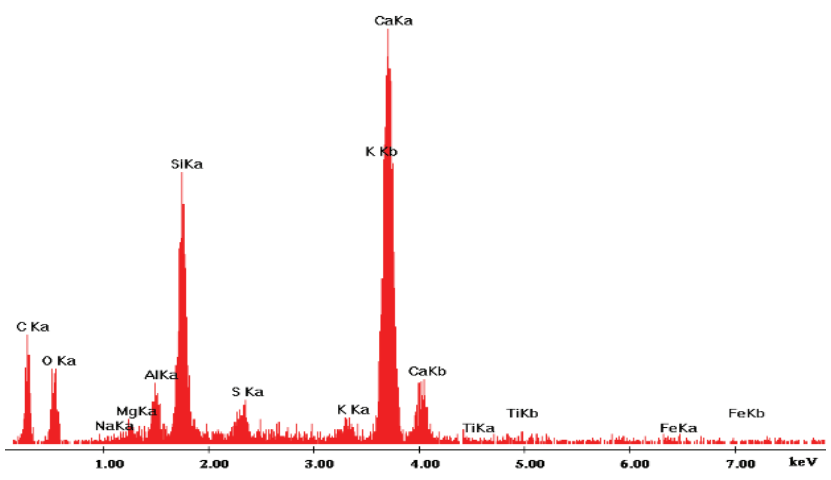

Fig. 6. Micrustructure of paste on CEM II/C (30\%V+10\%LL) binder with the addition of copper salt. Visible ash particle (point 1), limestone (point 2), C-S-H phase (EDS - point 3). 


\section{Conclusions}

The use of mineral additives replacing Portland cement clinker has many environmental and economic benefits. Decreasing the content of Portland clinker, the element of cement composition expensive in the production, is favorable for the reduction of $\mathrm{CO}_{2}$ emissions and allows the management of waste from other industries. In addition, the use of cement with significantly reduced clinker content for waste stabilization, including those containing heavy metals, is a cheap and effective method. The research has shown that the new CEM II/C and CEM VI composite cements, consisting of even more industrial waste, are suitable to use them as matrices for the immobilization of heavy metals. Batch-based tests proved that $\mathrm{Cu}, \mathrm{Zn}$ and $\mathrm{Pb}$ immobilization levels were on the average for these matrices respectively from $99.87 \%$ for 7-day mortars to $100 \%$ for 28 and 90 -day matrices. It was only chromium that its immobilization level lowered to $97.73 \%$ for 7 day samples on CEM II/C fly ash-lime cement (30\% V + $10 \%$ LL) to about $99.71 \%$ for 90 -day matrices on CEM VI slag-fly ash cement ( $45 \% \mathrm{~S}-10 \% \mathrm{~V})$. The studies showed the correlation between the composition of the applied composite cements and the degree of immobilization of heavy metals in the mineral matrices made thereof. Moreover, depending on the purpose of the material/object, the appropriate test method should be selected, as the results obtained are influenced by the type of materials exposure, environmental factors or form of the tested material (monolith or disintegrated material).

\section{References}

1. A. Vollpracht, W. Brameshuber, Cem. Concr. Res. 79, 76-92 (2016)

2. H. Lu, F. Wei, J. Tang, J. P. Giesy, Jour. Environ. Manag. 169, 319-327 (2016)

3. W. Gwenzi, N. M. Mupatsi, Waste Manag. 49, 114123 (2016)

4. D. Kalarus, T. Baran, M. Ostrowski, Sc. Works of ICBM. 25, 7-17 (2016),

5. C. Rosik-Dulewska, U. Karwaczyńska, ŚrodkowoPom. Tow. Nauk. Ochr. Śr. 10, 2005-2019(2008)

6. A. Król, Przem. Chemiczny 10, 971-973 (2007)

7. F. Song, L. Gu, N. Zhu, H. Yuan, Chemosphere 92, 4, 344-350 (2013)

8. A. Król, D. Jagoda, Cem. Wap. Bet. 2, 90-101 (2012)

9. W. Müllauer, R. E. Beddoe, D. Heinz, Cem. Concr. Comp. 58, 129-139 (2015)

10. M. A. Cinquepalmi, T. Mangialardi, L. Panei, A. Evangelista Paolini, L. Piga, Jour. Hazard. Mat. 151, 2-3, 585-593 (2008)

11. Md. A. Habib, N. Md. Bahadur, A. J. Mahmood, Md. Anarul Islam, Jour. Saud. Chem. Soc. 16, 3, 263-269 (2012)
12. A. Król, Uwalnianie metali ciężkich z kompozytów mineralnych $z$ uwzględnieniem oddziaływania środowiska (Wydawnictwo Politechniki Opolskiej, Opole, 2012)

13. I. Buj, J. Torras, M. Rovira, J. de Pablo, Jour. Hazard. Mat. 175, Issues 1-3, 789-794 (2010)

14. A. Król, Archit. Civil Eng. Environ. 4, 3, 71-76 (2011)

15. J. Kuterasińska, Cem.Wap., Bet. 4, 250-257 (2012)

16. A. Król, Environ.1 Protect. Eng. 38, no 4, 29-40 (2012)

17. A. Akyıldız, E. T. Köse, A. Yıldız, Constr. Build. Mat. 138, 326-332 (2017)

18. X.D Li, C.S Poon, H Sun, I.M.C Lo, D.W Kirk, Jour. Hazard. Mat. 82, 3, 215-230 (2001)

19. J. Androniuk, C. Landesman, P. Henocq, A. G. Kalinichev, Phys. Chem. Earth, 99, 194-203 (2017)

20. Q.Y. Chen, M. Tyrer, C.D. Hills, X.M. Yang, P. Carey, Waste Man., 29, 1, 390-403 (2009)

21. I. Navarro-Blasco, A. Duran, R. Sirera, J.M. Fernández, J.I. Alvarez, J. Hazard. Mat. 260, 89-103 (2013)

22. EN 197-1 Cement - Part 1: Composition, requirements and conformity criteria for common cements (2012)

23. pr EN 197-1Cement - Part 1: Composition, specifications and conformity criteria for common cements (rev. June 2014).

24. M. Dell'Orso, T. Mangialardi, A. Evangelista Paolini, L. Piga, Jour.Hazard. Mat. 227-228, (2012)

25. Y. J. Du, M. Li Wei, K. R. Reddy, Z. Peng Liu, F. Jin, Jour.Hazard. Mat. 271, 131-140 (2014)

26. A. P. Galvín, J. Ayuso, J. Ramón Jiménez, F. Agrela, Waste Man. 32, 1, 88-95 (2012)

27. A. Król, K. Mizerna, Conference (SEED) Krakow, POLAND Book Series: E3S Web of Conferences, Volume: 10, Article Number: UNSP 00050, (2016)

28. Construction Products Directive - CPD 89/106/EEC, (1989)

29. K.. Mizerna, A. Król, Ecol. Eng. 47, 151-156 (2016),

30. EN 12457-4 Characterization of waste. Leaching. Conformity test for leaching of granular waste materials and sludge. Part 2: Single-stage portion test at a liquid to solid ratio of $10 \mathrm{l} / \mathrm{kg}$ for materials with particle size less than $10 \mathrm{~mm}$ (with or without size reduction) (2006)

31. EA NEN 7375 Leaching characteristics of moulded or monolithic building and waste materials. Determination of leaching of inorganic components with the diffusion test. The tank test. (2004)

32. EN 196-1 Methods of testing cement. Part 1. Determination of strength. (2006) 